\title{
Hasil Belajar Peserta Didik pada Mata Pelajaran Pendidikan Pancasila dan Kewarganegaraan Menggunakan Model Pembelajaran Kooperatif
}

\author{
Yulita Pujilestaria ${ }^{\mathrm{a}, 1 *}$, Sri Putri Utami Alawiyah ${ }^{\mathrm{b}, 2}$ \\ a,bProgram Studi Pendidikan Pancasila dan Kewarganegaraan, \\ Fakultas Keguruan dan Ilmu Pendidikan, Universitas Pamulang, Tangerang Selatan \\ 1yulitapujilestari13@gmail.com; ${ }^{2}$ putriutami688@gmail.com; \\ *korespondensi penulis
}

Naskah diterima: 05-02-19, direvisi: 24-02-19, disetujui: 15-03-19

DOI: http://dx.doi.org/10.32493/jpkn.v6i1.y2019.p25-36

\begin{abstract}
Abstrak
Proses belajar mengajar tidak selalu menyampaikan informasi kepada siswa, tetapi membutuhkan keterlibatan siswa secara mental serta fisik. Penelitian ini mempunyai tujuan yaitu agar dapat mengetahui ada atau tidaknya pengaruh positif dan signifikan antara penerapan Model Pembelajaran Kooperatif Tipe STAD Terhadap Hasil Belajar Siswa pada Mata Pelajaran Pendidikan Pancasila dan Kewarganegaraan di SMK Yapia Parung. Pendekatan kuantitatif dipergunakan pada penelitian ini, dengan metode penelitian Purposive Sampling. Atas hal demikian dapat dijelaskan bahwa ada pengaruh positif dan signifikan antara penerapan Model Pembelajaran Kooperatif STAD (Student Team Achievement Division) terhadap Hasil Belajar Siswa di Mata Pelajaran Pancasila dan Pendidikan Kewarganegaraan pada Siswa Kelas X SMK Yapia Parung.
\end{abstract}

Kata-kata kunci: model STAD; hasil belajar; pembelajaran PPKn

\section{Abstract}

Teaching and learning process does not always convey information to students, but requires student involvement mentally and physically. The purpose of this research is to be able to know whether or not there is a positive and significant influence between the application of the STAD Type Cooperative Learning Model to Student Learning Outcomes in Pancasila and Civics Education Subjects at SMK Yapia Parung. The quantitative approach was used in this study, with the Purposive Sampling research method. For this matter it can be explained that there is a positive and significant effect between the application of the STAD (Student Team Achievement Division) Cooperative Learning Model to Student Learning Outcomes in Pancasila Subjects and Citizenship Education in Class $X$ Students of SMK Yapia Parung.

Keywords: model STAD; learning outcomes; civics learning 


\section{Pendahuluan}

Aspek penting dalam dunia pendidikan bahwa dalam mencapai tujuan bersama Negara dalam mencerdaskan anak bangsa perlulah di imbangi dengan adanya peranan pengajar sebagai fasilitator dalam proses pembelajaran. Dalam kehidupan bermasyarakat diperlukan adanya usaha manusia itu sendiri dalam aktivitas yang universal yang bersifat memanusiakan mausia.

Pendidikan ialah upaya terencana yang dilakukan semua masyarakat serta pemerintah dalam aktivitas pengajaran maupun bimbingan, dengan pelatihan, yang berjalan apakah di sekolah ataupun di luar sekolah sepanjang hidup agar mampu menyiapkan siswa untuk berperan didalam beberapa lingkungan tepat di masa yang akan datang.

Di aktivitas belajar mengajar, potensi pengembangan siswa dapat dilakukan secara keseluruhan dan terintegrasi.

"Pendidikan berfungsi untuk mengembangkan kemampuan dan membentuk karakteristik yang bermartabat dan peradaban bangsa dalam konteks kehidupan intelektual bangsa (UU RI No.20, 2003). Berdasarkan fungsi pendidikan nasional di atas, peran guru mewujudkan keberhasilan misi pendidikan dan belajar dan mengajar di sekolah. Guru bertanggung jawab dalam mengatur, mengarahkan, serta menciptakan suasana kondusif yang mendorong siswa untuk melakukan kegiatan ".

Pendidikan dalam negara indonesia mempunyai fungsi untuk pengembangan kemampuan serta peningkatkan kualitas hidup serta martabat masyarakat Indonesia dalam konteks dapat mengaktualkan tujuan nasional. Pendidikan nasional memiliki tujuan agar membuat cerdas kehidupan warganegara dan memajukan bangsa Indonesia secara keseluruhan, yaitu orang-orang yang beriman serta bertaqwa kepada Allah SWT dan berbudi tinggi, mempunyai kognitif serta keterampilan, kesehatan fisik serta spiritual, budi pekerti yang teguh serta mandiri serta sosial dan tanggungjawab nasional. (UU.RI.Bab II, Mzm 3 dan 4).

Termuat didalam Peraturan Pemerintah Nomor 19 tahun 2005 Bab 1 Pasal 1 Ayat 6 menyatakan sesungguhnya "Standar proses ialah standar pendidikan nasional yang berkaitan dengan pelaksanaan pembelajaran di unit pendidikan untuk mencapai standar kompetensi lulusan" (Depdiknas, 2006).

Untuk menjalankan fungsinya dan untuk mencapai tujuan-tujuan ini, yang pertama-tama digambarkan sebagai tujuan institusional dan kemudian tujuan kurikuler, dan tujuan instruksional, peran dan fungsi sistem dan tahap belajar dan mengajar dan ternyata menjadi begitu penting, sehingga sangat menentukan. hubungan guru dan siswa dalam proses membutuhkan dukungan luas dan efektif dengan sarana pembelajaran atau sarana pendidikan.

Dengan demikian jelas bahwa sistem baru menuntut atau memerlukan faktorfaktor kondisional baru. Baik dalam fasilitas fisik maupun psikologis. Selain kebutuhan akan guru yang mempunyai kemampuan serta keterampilan yang lebih 
memadai, cara kerja serta sikap yang baru dibutuhkan, perlengkapan yang lebih lengkap, serta sistem administrasi yang tertib.

Dalam suatu tahap belajar mengajar, peran guru sebagai pengajar yaitu memberikan dukungan, kesempatan bagi siswa dalam menerapkan ide serta strategi mereka didalam pembelajaran. Didalam pembelajaran yang berdasarkan pada pemahaman konstruktivis, siswa diberi kesempatan untuk dapat menggunakan strategi siswa sendiri dengan belajar secara sadar, serta guru mengarahkan siswa ke tingkat pengetahuan yang lebih tinggi. Setidaknya ada beberapa hal yang mengarah pada anggapan bahwa PPKn adalah pelajaran yang sulit dan menjemukan.

Tahapan belajar mengajar terjadi karena hubungan diantara siswa serta lingkungan. Dan karena hal lingkungan memerlukan pengaturan berbagai macam rupa sehingga tanggapan siswa muncul terhadap perbaikan sikap yang diharapkan. Regulator lingkungan meliputi: Analisis Kebutuhan Siswa, Keistimewaan anak didik, Perumusan Tujuan, Penetapan Bahan Belajar, Penunjukan langkah yang Tepat, sarana belajar mengajar yang Disesuaikan.

Agar pelaksanaan belajar mengajar dapat berlangsung dengan sempurna serta hasilnya dapat diandalkan, peningkatan dalam mengajar diarahkan sesuai pengelolaan transfer ilmu. Dengan demikian bagaimana peran strategi belajar mengajar dapat dikembangkan di sekolah memanifestasikan hasil didikan yang searah dengan apa yang dicita-citakan.
Selain meningkatkan proses belajarmengajar (sebagai umpan balik untuk guru dan siswa), hasil evaluasi juga digunakan untuk menilai (memberikan angka) sejauh mana prestasi siswa terhadap tujuan pengajaran diajarkan, dan melaporkan perkembangan siswa ini kepada orang tua siswa. Selain itu, untuk berbagai keperluan administrasi serta untuk tujuan bimbingan dan konseling.

Namun pada fakta di lapangan, tidak sedikit guru yang ditemukan dalam tahap memberikan ilmu di dalam kelas masih banyaknya mempergunakan cara transfer ilmu yang monoton. Salah satu hal yang terjadi adalah di Sekolah Kejuruan Yapia Parung, bahwa guru dalam melakukan proses belajar didalam kelas menggunakan lebih banyak cara ceramah serta jarang menggunakan metode diskusi kelompok. Inilah yang menyebabkan lemahnya semangat menimba ilmu anak didik yang berakibat pada hasil belajar yang tidak optimal. Dalam hal ini, perbaikan diprioritaskan dalam proses penerapan proses transfer ilmu yang dilakukan oleh guru di sekolah. Menurunnya motivasi belajar siswa karena metode ceramahnya sudah jenuh dan gurulah yang menjadi pusat belajar mengajar. didalam hal tersebut siswa kurang diberi kesempatan agar dapat lebih aktif serta komunikatif.

Oleh karena itu pembelajaran di kelas yaitu guru yang merupakan pusat pembelajaran tetapi berubah menjadi siswa yang menjadi pusat pembelajaran dan lebih menyenangkan, maka perlu untuk mengubah model transfer ilmu yang sangat efektif, salah satunya ialah 
pengajaran kooperatif tipe STAD dengan para siswa ini dapat belajar aktif dengan siswa lain.

Belajar di kelas harus menjadi pusat pembelajaran tetapi harus diubah menjadi siswa yang menjadi pusat belajar mengajar sehingga dapat membuat suasana yang sangat menyenangkan. Hal demikian pemilihan dalam model pembelajaran harus tepat sasaran untuk menjadikan siswa lebih dapat aktif serta komunikatif dalam proses transfer ilmu.

Corey mengatakan (1986: 195)

Belajar ialah suatu tahapan area dimana seseorang secara sengaja dikelola untuk memungkinkannya berpartisipasi dalam perilaku tertentu didalam keadaan spesifik atau menghasilkan respons terhadap situasi tertentu, belajar adalah bagian ksusus dari pendidikan.

Berdasarkan American National Concil of Studies (NCSS), Pendidikan Kewarganegaraan ialah semua yang mencakup pengaruh positif untuk membentuk pandangan warga negara dalam peran mereka sebagai warga negara, baik dari pengaruh positif keluarga dan sekolah.

Nawawi mengatakan Hasil belajar imerupakan tingkat kesuksesan anak siswa didalam memperoleh materi pelajaran sekolah yang hasilkan didalam nilai yang terdapat pada hasil tes dalam mengetahui sejumlah materi pelajaran.

Dalam kegiatan mengajar kooperatif, peneliti lebih suka menggunakan model STAD dibandingkan dengan model pembelajaran NHT (Numbered Head Together), Jigsaw, TGT (Teams Games Tournament).
Proses pembelajaran dengan memakai STAD (Student Team Achievement Division) dimana keahlian didalam mempelajari konsep pembelajaran yang merupakan strategi di dalam pelatihan kemampuan siswa membutuhkan kemampuan tim untuk memproses strategi pembelajaran. Pembelajaran kooperatif tipe STAD (Student Team Achievement Division) pada hasil nilai anak didik di rumpun pelajaran Pendidikan Pancasila dan Kewarganegaraan memiliki banyak efek positif yang konsisten yang sangat terlihat di semua mata pelajaran. Dimana dalam belajar mengajar kooperatif tipe STAD dapat menjadikan alternatif terbaik dalam menyelesaikan masalah dalam proses transfer ilmu yang dapat membuatnya lebih efektif serta efisien. Para siswa dapat menjadi sangat aktif dalam menimba ilmu serta akan meningkatkan hasil belajar.

Agar tercapai tujuan bersama didalam proses transfer ilmu, kualitas pengajaran paling berpengaruh didalam peningkatkan hasil belajar siswa, selain itu apakah pembelajaran ini efektif atau tidak dan hasil belajar rendah atau tinggi ditentukan dari kualitas proses pengajaran di kelas. Siswa dalam proses pembelajaran diharapkan dapat mengembangkan bakat, ini sangat terarah dan perhatian yang intens untuk mencapai sasaran yang telah ditetapkan sejak awal. Meskipun dalam menerima pelajaran siswa masih mengalami masalah seperti minat belajar yang masih rendah. Siswa dalam harus dapat menyesuaikan diri secara giat dan komunikatif dalam tahap pengkajian dengan mempergunakan model 
pembelajaran kooperatif tipe STAD sehingga cara pembelajaran bisa berjalan dengan baik dan lancar bisa membantu sesama kelompok. Partisipasi aktif dalam memahami materi diperlukan dalam kelompok untuk menguasai pelajaran.

STAD (Student Team Achievement Division) adalah merupakan suatu cara belajar mengajar kooperatif yang memberi kelompok berkekuatan berbeda latihan untuk mempelajari konsep dan keahlian, bersama semua siswanya (slavin, 1986,1995).

Menurut wina (2008: 242) menjelaskan didalam belajar mengajar kooperatif tipe Student Division Achievement Division (STAD) ialah cara pembelajaran yang memanfaatkan sekumpulan atau tim kecil, yaitu alebih kurang 4-5 orang yang memiliki berbagai kepandaian akademik, jenis kelamin, ras atau etnis yang berbeda (heterogen).

Isjoni mengatakan (2007: 70) STAD benar-benar cocok untuk mengajar bahan ajar yang tujuannya jelas didefinisikan, misalnya perhitungan dan aplikasi matematika, penggunaan bahasa, geografi, dan keterampilan dalam menggunakan peta.

Di STAD, anak didik dibagi menjadi kurang lebih kelompok bersama-sama empat anggota dari berbagai kepandaian, jenis kelamin, serta suku. Guru mentransfer materi pelajaran serta anak didik dalam kelompok membenarkan mengenai anggota seluruh kelompok harus dapat memahami pelajaran. Alhasil anak didik mengambil kuis individu tentang materi, dan pada saat itu mereka tidak diperbolehkan saling mendukung.
Semua skor kuis anaak didik dibandingkan dengan skor rata-rata mereka sendiri yang didapat lebih dahulu, dan nilai tersebut dinilai beralaskan seberapa tinggi pengembangan yang dapat diraih atau seberapa tinggi skor tersebut dapat melebihi skor sebelumnya. Point ini kemudian ditambahkan akan mendapatkan skor kelompok, serta kelompok yang dapat meraih standar ini dapat mencapai nilai yang baik. semua aliran kegiatan, diawali dari penjelasan guru hingga kerja kelompok serta kuis, terkadang membutuhkan tiga hingga lima pertemuan kelas.

Slavin juga mengatakan bahwa: "ide utama di balik STAD adalah memotivasi siswa untuk dapat saling mendukung dan membantu satu sama lain untuk menguasai keterampilan yang diajarkan oleh guru." Ketika anak siswa berkeinginan berkelompok mencapai skor, sesama siswa harus mendukung rekan-rekan kelompok mereka dalam pelajaran pembelajaran. Siswa harus mendukung tim kelompok agar mengerjakan yang optimal, menunjukkan aturan bahwa belajar itu sangat berguna, bermakna, serta menggembirakan. Siswa diberi batas untuk dapat berkolaborasi setelah materi yang diberikan oleh guru, hanya bukan saling mendukung saat menjalani kuis, sehingga anak didik wajib memahami materi (tanggung jawab individu). Siswa dapat bekerja berpasangan dan bertukar jawaban, membahas ketidaksetaraan, serta silih membantu, siswa dapat membahas pendekatan untuk menyelesaikan kesulitan, atau anak didik dapat 
mengajukan pertanyaan tentang isi materi yang dipelajari siswa. Mereka membimbing sekelompok teman dan memperhitungkan kelebihan serta kekurangan mereka untuk membantu mereka tercapai melaksanakan tes. Karena nilai kelompok didasarkan pada perkembangan yang dibuat oleh anak didik pada nilai sebelumnya (peluang keberhasilan yang sama), siapa pun mampu sebagai kelompok "bintang" didalam satu minggu, karena nilai lebih baik dari lebih dahulu atau karena kertas dianggap sempurna, sehingga selalu menghasilkan skor maksimum tanpa mempertimbangkan nilai rerata poin anak didik sebelumnya.

Pengaruh model pembelajaran kooperatif STAD (Student Team Achievement Division) terhadap hasil belajar secara konsisten menunjukkan efek yang baik didalam semua pelajaran. Pembelajaran kooperatif ialah solusi yang tepat untuk masalah yang memberikan anak didik kesempatan untuk berhubungan secara kooperatif serta tidak secara dangkal dari latar belakang etnis yang berbeda. Model belajar mengajar kooperatif secara khusus menggunakan kekuatan sekolah untuk menghilangkan perbedaan didalam kehadiran anak didik dari bermacam latar belakang etnis atau etnis dalam meningkatkan hubungan antar kelompok. Dalam pembelajaran ini, siswa diharuskan untuk pergi melampaui penghargaan serta tugas di kelas dan penghargaan oleh guru, yang mencoba untuk mengkomunikasikan tindakan.

Model pembelajaran ini disusun sedemikian rupa sehingga semua siswa dapat kesempatan agar memberikan kontribusi yang substansial kepada tim mereka; posisi anggota tim sama, pembelajaran kooperatif memberikan peluang harian untuk kontak pribadi yang intens antara siswa dengan kondisi yang berbeda.

Pembelajaran kooperatif ialah model pembelajaran yang menekankan kegiatan kolaboratif diantara para anak didik didalam pembelajaran kelompok, mendalami materi pelajaran, serta menyelesaikan masalah secara bersamasama secara kooperatif. Pendekatan pembelajaran kooperatif memerlukan perubahan tujuan pembelajaran dari hanya mentransfer informasi ke pengetahuan konstruktif (konstruksi pengetahuan) oleh individu melalui pembelajaran kelompok. Namun, dogma ini sering tidak jelas, karena dari berbagai literatur mengenai pembelajaran kooperatif serta kolaboratif, informasi pembelajaran serta implementasi pembelajaran kooperatif umumnya berfokus pada struktur serta manajemen pembelajaran. Hal tersebut dapat dilihat dari segi distribusi gender, jumlah siswa di kelas, dan strategi penugasan. Dengan demikian semua siswa akan aktif dalam menyelesaikan tugas.

STAD yang dipakai didalam semua mata pelajaran, dimulai dari matematika, bahasa, seni, hingga ilmu sosial serta ilmu ilmiah lainnya, serta telah dipergunakan dari anak siswa kelas dua sampai dengan perguruan tinggi. Ide esensial STAD ialah memacu anak didik agar dapat saling membantu serta menopang diantara satu sama lain didalam memiliki kepandaian 
yang diajarkan oleh guru. Dalam hal anak didik berkeinginan kelompok mereka memperoleh penghargaan tim, perserta didik harus meringankan rekan tim mereka menekuni materi. Diantara mereka diarahkan membantu rekan tim mereka untuk mengerjakan yang terbaik, membuktikan norma maka belajar itu sangat utama, berharga serta menggembirakan. Anak didik bekerja bersama setelah guru menjelaskan materi pelajaran. Mereka dapat bekerja secara berpasangan dan menyamakan jawaban mereka, mendiskusikan perbedaan, serta saling mendukung jika ada yang salah didalam memahami. Mereka dapat mendiskusikannya dari pendekatan memecahkan masalah, atau para siswa juga dapat bersaing untuk memberikan kuis tentang objek yang para siswa pelajari. Mereka bekerja bersama rekan satu kelompok mereka, menilai kekuatan serta kelemahan mereka untuk membantu mereka berhasil dalam kuis.

Pembelajaran kooperatif tipe STAD ini pertama kali dikembangkan oleh Robert Slavin bersama teman-temannya di Universitas John Hopkin (dalam Slavin, 1995). Di Indonesia, dasar untuk menggunakan model STAD sangat cocok di mana pembelajaran kooperatif menjadi salah satu model pembelajaran paling simpel, sehingga ketika guru memulai pemebelajaran dengan model ini proses pembelajaran akan menjadi lebih efektif dan komunikatif.

Pembelajaran kooperatif model STAD memiliki lima komponen yang essensial termasuk presentasi kelas, pembelajaran kelompok, kuis, skor pengembangan serta penghargaan kelompok, selain model STAD pula menjadi siklus kegiatan yang terorganisir.

Kemudian, Standar yang diterapkan dalam penggunaan model STAD di Indonesia ialah bahwa guru dapat memaparkan pembelajaran dengan siswa dengan bekerja sama dengan tim untuk memastikan bahwa semua anggota kelompok telah menguasai materi. Model STAD dengan pendekatan pembelajaran kooperatif yang dapat menekankan interaksi dan kegiatan siswa untuk dapat saling membantu dan memotivasi penguasaan materi agar mendapatkan hasil belajar yang maksimal.

Berdasarkan latar belakang masalah dan identifikasi masalah, masalah tersebut dapat dirumuskan sebagai berikut: Apakah ada pengaruh pada penerapan model pembelajaran kooperatif tipe STAD terhadap hasil belajar para siswa di Pancasila dan Pendidikan Kewarganegaraan pada siswa kelas X SMK Yapia Parung Tahun Akademik 2017/2018?

Melihat motif kerangka masalah dan identifikasi masalah yang begitu luas, maka penulis membatasi masalah diantaranya: penerapan Model Pembelajaran Tipe STAD Terhadap Subjek Hasil Belajar Siswa pada Mata Pelajaran Pancasila dan Pendidikan Kewarganegaraan di Kelas X SMK Yapia Parung 2017 / Tahun Akademik 2018.

Hipotesis dari penelitian ini ialah bahwa ada pengaruh penerapan Model Pembelajaran Kooperatif Tipe STAD (Student Team Achievement Division) Terhadap Hasil Belajar Siswa Mata 
Pelajaran Pendidikan Pancasila dan Kewarganegaraan Kelas X di SMK Yapia Parung Tahun Akademik 2017/2018.

Tujuan dari penelitian ini yaitu untuk mengetahui pengaruh penerapan Model Pembelajaran Kooperatif Team Student Achievement Division (STAD) terhadap Hasil Belajar Siswa pada Mata Pelajaran Pendidikan Pancasila dan Kewarganegaraan di SMK Yapia Parung.

Manfaat dari segi akademis ialah menambah pengetahuan tentang model didalam pembelajaran, bahwa dengan menggunakan model pembelajaran tipe STAD (Student Team Achievement Division) ke hasil pembelajaran pendidikan kewarganegaraan kami dapat membantu tujuan pendidikan di Indonesia yang sejalan dengan karakteristik bangsa.

Diharapkan Manfaat praktis dalam penelitian ini yaitu memperoleh manfaat diantaranya : Bagi Program Studi PPKn dengan penelitian ini dapat bersumbangsih pemikiran tentang pemecahan masalah dengan menerapkan pembelajaran kooperatif tipe STAD agar meningkatkan antusiasme siswa didalam pengajaran di kelas, Untuk siswa dengan pembelajaran PPKn melalui model tipe pembelajaran STAD mengharapkan pemaparan siswa di depan kelas, pembentukan kelompok, kuis, skor kemajuan individu serta kemajuan kelompok. Para siswa dapat bertambah aktif serta komunikatif didalam kegiatan belajar. Agar guru dapat menambahkan wawasan ke dalam cara dan metode pembelajaran yang efektif dan menarik bagi anak didik, sehingga belajar mengajar didalam kelas tidak monoton dalam pembelajaran dan sebagai dasar untuk memotivasi siswa belajar didalam menentukan perencanaan pengembangan dalam penggunaan model STAD (Student Team Achievement Division ) tipe pembelajaran kooperatif.

Peningkatan kualitas untuk sekolah, pendidikan sekolah dicirikan dengan keberhasilan yang dicapai melalui model transfer ilmu yang tepat untuk mencapai prestasi yang akan meningkatkan kepercayaan masyarakat.

\section{Metode}

Metode kuantitatif merupakan metode yang terlama, dikarenakan cara ini telah dipakai sangat lama sehingga telah ditransmisikan sebagai cara dalam penelitian. Cara ini disebut metode positivistik sebab didasarkan atas filosofi positivisme. Metode ini adalah metode ilmiah dikarenakan telah melengkapi prinsip-prinsip ilmiah yang konkret / empiris, obyektif, terukur, rasional, dan logis. Metode ini disebut juga dengan metode penemuan, karena dengan metode ini dapat ditemukan dan dikembangkan beragam sains dan teknologi baru. Metode ini disebut kuantitatif dikarenakan ada data penelitian dalam bentuk angka serta analisis menggunakan statistik.

Metode yang dipakai didalam penelitian ini ialah purposive sampling, yaitu teknik pengambilan sampel dengan pertimbangan tertentu. Menurut Arikunto, makna Purposive Sampling adalah teknik pengambilan sampel tidak berlandaskan acak, regional atau strata, akan tetapi berdasarkan pada adanya 
Jurnal Pendidikan Kewarganegaraan

Vol. 6 No. 1 Maret 2019

pertimbangan yang fokus pada tujuan tertentu.

\section{Hasil dan Pembahasan}

Beralaskan hasil pengumpulan data yang telah diperoleh dengan mempergunakan angket serta test pada peserta didik SMK Yapia Parung. Didalam hasil pengumpulan data menggunakan angket didalam penelitian ialah model belajar mengajar kooperatif tipe STAD (Student Team Achievement Division.)

A. Hasil pengumpulan data dengan angket model pembelajaran kooperatif tipe STAD (Student Team Achievement Division)

Hasil penelitian dengan menggunakan angket angket model pembelajaran kooperatif tipe STAD (Student Team Achievement Division) memperoleh sampel sebanyak 66 peserta didik dengan data tertinggi yaitu 125 dan data terendah 70 , banyaknya kelas 7 , panjang interval 8, dengan memperoleh rentang data sebanyak 55, rata-rata atau mean sebesar 92, nilai tengah atau median sebesar 93, modus 100,9, varian 128, dan simpangan baku 11,31.

\section{Tabel 2. Deskripsi Model STAD}

\begin{tabular}{lll}
\hline No & Ukuran data & Nilai \\
\hline 1 & Mean & 92 \\
2 & Median & 93 \\
3 & Modus & 100,9 \\
4 & Varians (S2) & 128 \\
5 & Simpangan & 11,31 \\
& Baku (S) & \\
\hline
\end{tabular}

B. Hasil belajar peserta didik

Hasil penelitian terkait dengan hasil belajar peserta didik dengan memperoleh rentang data 57 , dengan data tertinggi 86,58 dan data terendah 29,97, banyak kelas 7 , interval kelas 8 , rata-rata atau mean 66,49 , nilai tengah atau median 67,9, modus 78 , varian 197, dan simpangan baku 14.

Tabel 1. Deskripsi Hasil Belajar

\begin{tabular}{lll}
\hline No & Ukuran Data & Nilai \\
\hline 1 & Mean & 66,49 \\
2 & Median & 67,9 \\
3 & Modus & 78 \\
4 & Varians $\left(S^{2}\right)$ & 197 \\
5 & Simpangan Baku & 14 \\
& $(\mathrm{~S})$ & \\
\hline
\end{tabular}

Hal tesebut dikonsultasikan dengan X2Tabel pada taraf signifikansi $a=0,05$ dan derajat kebebasan (dk) $66-1=65$ diperoleh 84,82. Maka X2hitung $=-1,328$ $<$ X2Tabel 84,82, maka data berasal dari populasi yang berdistribusi normal.

Perolehan analisis menunjukan bahwa terdapat pengaruh yang positif dan signifikan antara Pengaruh Penerapan Model Pembelajaran Kooperatif Tipe STAD Terhadap Hasil Belajar Peserta Didik Kelas X Di SMK Yapia Parung. Dengan dibuktikan diperoleh $r_{\text {hitung }}$ 0,29 lebih besar daripada $r_{\text {tabel }}$ pada signifikan a $=5 \mathrm{~N}-66-2=64$ diperoleh $\mathrm{r}_{\text {tabel }}$ 0,2042 . Sehingga dapat di interpretasikan bahwa Terdapat Pengaruh Yang Positif Dan Signifikan Antara Model STAD Terhadap Hasil Belajar Peserta Didik Kelas X Di SMK Yapia Parung. 
Jurnal Pendidikan Kewarganegaraan

Vol. 6 No. 1 Maret 2019

Tabel 3. Interpretasi Nilai Koefisien Korelasi

\begin{tabular}{ll}
\hline Interval Koefisien & $\begin{array}{l}\text { Tingkat } \\
\text { Hubungan }\end{array}$ \\
\hline $0,00-0,199$ & Sangat Rendah \\
$0,20-0,399$ & Rendah \\
$0,40-0,599$ & Sedang \\
$0,60-0,799$ & Kuat \\
$0,80-1,00$ & Sangat Kuat \\
\hline
\end{tabular}

Bersandarkan perolehan perhitungan diatas, bahwa dapat disimpulkan pada butir pernyataan memiliki realibilitas kuat, dikarenakan 0,64 > 0,60.

Hasil penelitian dengan instrumen model STAD berdistribusi normal dan untuk hasil belajar berdistribusi normal serta linier, kemudian langkah selanjutnya adalah dengan menganalisis uji t. dimana pengujian hipotesis diperoleh hasil sebagai berikut :

$\mathrm{H} 1$ = Terdapat Pengaruh Positif Dan Signifikan Antara Model STAD Terhadap Hasil Belajar Peserta Didik Di SMK Yapia Parung.

$\mathrm{H}_{0}=$ Terdapat Pengaruh Positif Dan Signifikan Antara Model STAD Terhadap Hasil Belajar Peserta Didik Di SMK Yapia Parung.

Berdasarkan hasil perhitungan pengujian tingkat keberhasilan pengaruh variabel $\mathrm{X}$ terhadap variabel $\mathrm{Y}$, maka dapat ditarik kesimpulan bahwa variabel $\mathrm{X}$ memiliki pengaruh terhadap variabel $\mathrm{Y}$ karena thitung $>$ ttabel $(\mathrm{N}-\mathrm{k}=66-31=$ $35={ }^{\alpha}=0,05=2,03$ ) yang berarti thitung $=2,13>2,03$. Dengan demikian maka H0 ditolak dan H1 diterima. Dengan ini berarti adanya pengaruh positif dan signifikan antara Penerapan Model Pembelajaran Kooperatif Tipe STAD (Student Team Achievement Division)
Terhadap Hasil Belajar Peserta Didik Mata Pelajaran Pendidikan Pancasila dan Kewarganegaraan Di Kelas X SMK Yapia Parung Tahun Ajaran 2017/2018.

\section{Kesimpulan}

Simpulan Penelitian Ini Hasilnya tentang Penerapan Model Pembelajaran Kooperatif Tipe STAD Terhadap Hasil Belajar Peserta Didik Mata Pelajaran Pendidikan Pancasila Dan Kewarganegaraan Di Kelas X SMK Yapia Parung yang peneliti dapat lakukan ialah kesimpulan sebagai berikut.

Berdasarkan uji koefisien korelasi didapatkan pada $r_{x y}(0,25) r_{\text {tabel }}>(0$, 2042). Pengujian hipotesis dengan menggunakan uji $\mathrm{t}$ diperoleh data $t_{\text {hitung }}$ 2,13 dan $t_{\text {tabel }} 2,03$ dengan kriteria pengujian jika $t_{\text {hitung }}<t_{\text {tabel }}$ maka $\mathrm{H}_{0}$ diterima dan $\mathrm{H}_{1}$ ditolak dan jika $t_{\text {hitung }}>$ $\mathrm{t}_{\text {tabel }}$ maka $\mathrm{H}_{0}$ ditolak dan $\mathrm{H}_{1}$ diterima. Dengan demikian makan $\mathrm{H}_{0}$ ditolak dan $\mathrm{H}_{1}$ diterima karena $\mathrm{t}_{\text {hitung }}>\mathrm{t}_{\text {tabel }}$ hal ini berarti terdapat pengaruh positif dan signifikan antara penerapan model pembelajaran STAD terhadap hasil belajar peserta didik kelas $\mathrm{X}$ di SMK Yapia Parung.

Dapat disimpulkan maka terbukti bahwa variabel penerapan model pembelajaran kooperatif tipe STAD mempunyai korelasi yang positif dan signifikan terhadap hasil belajar peserta didik pada mata pelajaran Pendidikan Pancasila dan Kewarganegaraan di kelas X SMK Yapia Parung. Dengan demikian hipotesis didalam penelitian ini membuktikan bahwa penerapan model pembelajaran kooperatif tipe STAD 
terhadap hasil belajar peserta didik pada mata pelajaran Pendidikan Pancasila dan Kewarganegaraan di kelas X SMK Yapia Parung tahun ajaran 2017/2018 dapat diterima.

Berdasarkan kesimpulan diatas bahwa Dalam penelitian ini banyak mengandung implikasi bahwa penerapan model pembelajaran tipe STAD akan mempengaruhi hasil peserta didik. Implikasi ini dapat memberikan peningkatan pembelajaran dalam perbaikan hasil belajar anak didik. selain itu, telah dibuktikan bahwa penerapan model pembelajaran kooperatif tipe STAD dapat dijadikan sebagai model pembelajaran yang baik yang kelak dipakai para tenaga pendidik didalam tahap pembelajaran dan pengajaran.

Didalam penelitian ini peneliti telah meneliti mekakukannya dengan semaksimal mungkin, peneliti sangat menyadari masih banyak sekali kekurangan serta keterbatasan dalam penelitian. Oleh karena itu diharapkan adanya penelitian lebih jauh agar memperoleh produk yang diharapkan dan menjadikan nya hasil yang makin baik juga dapat berarti untuk peserta didik, guru atau peneliti lain pada umumnya.

Didalam belajar mengajar kooperatif tipe STAD ini, anak didik mempunyai pokok peran utama dalam proses pembelajaran, dimana anak didik dituntut untuk aktif selama pembelajaran berlangsung, dengan adanya pembelajaran dengan model STAD ini dapat mempermudah peserta didik didalam menafsirkan materi dan dapat menerapkannya dalam berinteraksi di kelompoknya masing-masing.

Bagi dewan pengajar didalam Pendidikan Pancasila dan Kewarganegaraan diharapkan sebelum memulai pembelajaran dan pengajaran harus sudah mempersiapkan administrasi pembelajaran macam Rencana Pelaksanaan Pembelajaran (RPP), Silabus, Lembar Kerja Siswa (LKS), dan instrumen evaluasi pembelajaran hasil peserta didik agar dalam proses pembelajaran dan pengajaran agar mampu memperoleh nilai yang maksimal dan sesuai dengan apa yang diharapkan.

Bagi pengelola SMK Yapia Parung, agar tenaga pengajar dapat menciptakan pembelajaran dengan suasana yang menyenangkan agar dapat terciptanya pembelajaran yang aktif dan komunikatif, dengan penerapan model pembelajaran yang tepat dapat meningkatkan proses pembelajaran peserta didik, sehingga hasil belajar yang maksimal sesuai kompetensi yang diharapkan.

Bagi peserta didik seharusnya dapat bekerja sama secara aktif dalam tahap pembelajaran, agar peningkatan belajar yang diharapkan pun akan terwujud.

\section{Referensi}

Alhakim, S. (2014). Pendidikan Kewarganegaraan dalam konteks indonesia. Malang: Madani (Kelompok Intrans Publishing.

Aunurrahman. (2009). Belajar dan pembelajaran. Bandung : Alfabeta. 
Jurnal Pendidikan Kewarganegaraan

Vol. 6 No. 1 Maret 2019

Hamalik, O. (2010). Psikologi Belajar Dan Mengajar. Bandung: Sinar Baru Algesindo.

Hamalik, O. (2011). Proses Belajar Mengajar. Jakarta : Bumi Aksara

Hamalik, Oemar. 1994. Media pendidikan. Bandung : Citra Aditya Bakti

Hamidi, J. (2010). Civic education. Jakarta : Gramedia Pustaka Umum

Hardiani, I. (2012). Strategi Pembelajaran Terpadu. Yogyakarta : Familia

Jakni. (2014). Pendidikan Kewarganegaraan Di perguruan tinggi. Bandung : Alfabeta

Juliardi, B. (2014). Pendidikan Kewarganegaraan untuk perguruan tinggi. Jakarta: Raja Grafindo.

Kadir, A. (2012). Dasar-Dasar Pendidikan. Jakarta: Kencana Prenadamedia Group.

Komarudin. (2012). Ilmu kewarganegaraan. Pamulang: Asmoro Mediatama.

Komarudin. (2013). Strategi pembelajaran Pkn. Pamulang: Asmoro Mediatama.

Muhidin, A. (2005). Stastistik Pendidikan. Tanggerang Selatan : Unpam Press

Purwanto, N. (1988). Prinsip-prinsip dan teknik evaluasi pengajaran. Bandung: Remadja Karya CV.

Rusman. (2014). Model-model pembelajaran mengembangkan profesionalitas guru. Jakarta : PT. Raja Grafindo Persada
Sagala, S. (2013). Konsep Dan Makna Pembelajaran. Bandung: Alfabeta.

Shoimin, A. (2014). 68 Model Pembelajaran Inovatif Dalam Kurikulum 2013. Yogyakarta : Ar-Ruzz Media.

Siregar, E. (2015). Teori Belajar Dan Pembelajaran. Bogor: Ghalia Indonesia.

Slavin, R. E. (2005). Cooperative Learning. Bandung: Nusa Media.

Suardi, M. (2016). Pengantar Pendidikan Teori Dan Aplikasi. Jakarta: PT Indeks.

Sugiyono. (2013). Metode Penelitian Pendidikan. Bandung: Alfabeta.

Tim pengembang MKDP kurikulum dan pembelajaran. (2011). Kurikulum dan pembelajaran. Jakarta: Raja Grafindo Persada.

Uno, H. B. (2006). Perencanaan pembelajaran. Jakarta : Bumi Aksara.

Uno, H. B. (2014). Model Pembelajaran Menciptakan Proses Belajar Mengajar Yang Kreatif dan Efektif. Jakarta : Bumi Aksara

Wilis, D. R. (2011). Teori-teori belajar dan pembelajaran. Bandung: Erlangga. 